\title{
Index to Volume 145
}

\section{PART I-SUBJECTS}

Compiled by A. Stanley Thorley

Abbreviations: (C) denotes Correspondence CAT-Computerised Axial Tomography

DST_Dexamethasone Suppression Test ECT-Electroconvulsive Therapy REM-Rapid Eye Movement TRH-Thyrotropin Releasing Hormone

Acquired Immune Deficiency Syndrome (AIDS)-in New York City with particular reference to the psycho-social aspects: Neil Deuchar 612-619

Actometer: Validity of actometer and speech activity measures in the assessment of depressed patients: Hamish P. D. Godfrey and Robert G. Knight 159-163

Addendum: Past and present perceived attitudes of schizophrenics in relation to rehospitalisation (March. 1984, 144, 263-269): B. Baker et al (C) . 219

Adolescence: TRH response pattern in adolescent schizophrenic males: Lawrence DeMilio 649-651

Adrenoceptor Function: Effects of desipramine treatment upon central adrenoceptor function in normal subjects: $T$. H. Corn el al 139-145

Affective Disorders: Approaches to the evaluation and treatment of rapid-cycling affective illness; Peter P. RoyByrne et al 54.3-5.50

Psychosis in bipolar and unipolar affective illness with special reference to schizo-affective disorder: George Winokur (Lecture. November 1983) 236-242

Ageing: Genetics, ageing and dementia: A. F. Wright and L. J. Whalley 2(1-38

Agoraphobia and hyperthyroidism: T. H. Turner (C) 215216

Alcohol and sedative drug use in neurotic out-patients; D. S. Samarasinghe et al $45-48$

Allergy: Psychiatric study of patients with supposed food allergy: Keith J. B. Rix et al 121-126

Amputation: Dreams after amputation: Larry Burd (C) 448: Alistair J. Macdonald (C) 669; James E. B. Lindesay (C) 669

Annotation: Gestalt therapy in theory and in practice: Richard Tillett 231-235

Anorexia Nervosa and depression-reconsidering diagnostic criteria: Alan B. Levy and Katherine N. Dixon (C) 93

In a black Zimbabwean; T. Buchan and L. D. Gregory 3263.30

In Down's syndrome; D. J. Cottrell and A. H. Crisp (Case report) 195-196

Happy families; J. M. Heron and R. F. Leheup 136-138

Long-term outcome in 50 female patients: Anne Hall et al $4(1) 7-413$

Outcome of anorexia nervosa in males; Tom Burns and A. H. Crisp $\quad 319-325$

Psychosis in anorexia nervosa and bulimia; James I. Hudson et al $420-423$
Study of 34 twin pairs and one sęt of triplets: A. J. Holland et al $+1++19$

Anticholinergics see also Benzhexol: Abuse: G. P. Pullen et al (C) 671-672

Effect of anticholinergics on tardive dyskinesia. A controlled discontinuation study: W. Greil et al 304-310

Antidepressants: Changes occurring in appetite and weight during short-term antidepressant treatment; Brian Harris et al $645-648$

Anxiety Disorders: Mitral valve prolapse and anxiety disorders: Michael P. Chan et al (C) 216-217

No longer an enigma: Christopher Bass 447-448

Appetite: Changes occurring in appetite and weight during short-term antidepressant treatment: Brian Harris el al $645-648$

Autonomic Monitor for ECT; J. M. Watkins-Pitchford and F. Reynolds (Brief report) 551-554

Behaviour: Natural history of behavioural symptoms among severely and profoundly mentally retarded patients; $A$. H. Reidet al 289-293

Benzhexol (Trihexyphenidyl): Study of benzhexol abuse; John A. Crawshaw and Paul E. Mullen 300-303

Anticholinergic abuse; G. P. Pullen et al 671-672

Bereavement: Long-term outcome of bereavement: Tom Lundin 424-428

Bipolar Disorder: Family study of bipolar II disorder; W. Coryell et al 49-54

Psychosis in bipolar and unipolar affective illness with special reference to schizo-affective disorder; George Winokur (Lecture, November 1983) 236-242

Birmingham: Survey of prescribing of psychotropic drugs in a Birmingham psychiatric hospital: Stephen Edwards and Vinod Kumar 502-507

Books Reconsidered: Persuasion and Healing: J. D. Frank; Mark Aveline 207-211

Botswana: Modern or traditional? A study of treatment preference for neuropsychiatric disorders in Botswana; Jeremy R. Dale and David I. Ben-Tovim 187-192

Brief Reports: Autonomic monitor for ECT: J. M. WatkinsPitchford and F. Reynolds 551-552

Case report: psychomotor status-like episodes under haloperidol treatment: Y. Kaminer and H. Munitz 87-88

Co-existence of the Capgras and Ekbom syndromes: Jo-Ann McLaughlin and Andrew Sims 439-441

Depression, weight loss and the DST: Alec Coppen et al 8890

Doctors and nurses use of the word 'confused'; C. J. Simpson 441-443

Investigation of the aetiology of chronic headache: the role of headache models; Ira D. Turkat et al 665-666

Koro and psychosis: P. C. Ang and M. P. I. Weller 335

Koro-like symptoms in a non-Chinese subject: G. E. Berrios and S. J. Morley 331-334 


\section{SUBJECT INDEX}

Mental changes resulting from subdural haematoma; Donald W. Black 200-203

Psychophysiological assessment of expressed emotion in schizophrenia-a case example; Nicholas Tarrier and Christine Barrowclough 197-200

Relief of diazepam-withdrawal syndrome by shoplifting; Jeremy Coid 552-554

Serum immunoglobulin concentrations in patients admitted to an acute psychiatric in-patient service; Lynn E. DiLisi et al 661-665

Bristol: Psychiatric hospital admissions in Bristol. I. Geographical and ethnic factors: $B$. Ineichen et al $600-604$

II. Social and clinical aspects of compulsory admission; Glynn Harrison et al 605-611

Bulimia: Complications of bulimia nervosa; Kevin Healy (C) 93

Mood changes in bulimia nervosa; E. C. Johnson-Sabine et al $512-516$

Psychosis in anorexia nervosa and bulimia; James I. Hudson et al $420-423$

Camberwell: Community care in Camberwell: a two-year follow-up of a cohort of long-term users; Elizabeth Sturt 178-186

Cancer see also Malignancy. Hypocholesterolaemia in cancer and other causes of death in the mentally handicapped; $J$. Jancar et al 59-61

Capgras Syndrome: Co-existence of the Capgras and Ekbom syndromes; Jo-Ann McLaughlin and Andrew Sims (Brief report) 439-441

Case Reports: Anorexia nervosa in Down's syndrome; D. J. Cottrell and A. H. Crisp 195-196

Self-shooting of a phantom head; David Ames 193-194

Cerebral Dominance: Re-evaluation of the viral hypothesis: Is psychosis the result of retroviral integration at a site close to the cerebral dominance gene?; Timothy J. Crow 243253

Childbirth: Day-to-day mood changes after childbirth: further data; R. E. Kendell et al $\quad 620-625$

Children who poison themselves: I. Clinical comparison with psychiatric controls $127-132$

II. Prediction of attendance for treatment; E. A. Taylor and S. A. Stansfield 132-135

Classification and diagnosis of depression in school phobia; Israel Kolvin et al 347-357

Psychotic children with hallucinations; M. E. Garralda 74 77

Rejection of a child by his mother successfully treated after three years; I. F. Brockington and E. Brierley 316-318

Schizoid personality in childhood; Lorna Wing (C) 444. Reply; Ann Cull et al (C) 444-445

Circadian Rhythms and psychiatry; Christopher Thompson (Comments) 204-206. N. P. V. Nair and N. Hariharasubramanian $(\mathrm{C}) \quad 557-558$

Clinics: General practice psychiatric clinics, impact on psychiatric services: Peter Tyrer et al 15-19

Psychiatric clinics in general practice, an extension of community care; Peter Tyrer 9-14

Single-consultation assessment clinic; Linda $M$. Brown (C) 558
Clomipramine: Psychophysiological changes during pharmacological treatment of patients with obsessive compulsive disorder; Theodore P. Zahn et al 39-44

Clonidine: Effects of desipramine treatment upon central adrenoceptor function in normal subjects; T. H. Corn et al 139-145

Clorgyline: Psychophysiological changes during pharmacological treatment of patients with obsessive compulsive disorder; Theodore P. Zahn et al 39-44

Cognitive Therapy-training the patients; D. Peter Birkett (C) 95

Cognitive-behaviour therapy for depression; problems and perspectives; J. Mark G. Williams (Review article) 254 262

Evaluation of cognitive-behaviour therapy for depression in patients with multiple sclerosis; Nora A. Larcombe and Peter H. Wilson 366-371

Comments: Circadian rhythms and psychiatry; Christopher Thompson 204-206

Community Care in Camberwell: two-year follow-up of a cohort of long-term users; Elizabeth Sturt 178-186

General practice psychiatric clinics, impact on psychiatric services; Peter Tyrer et al 15-19

Psychiatric clinics in general practice, an extension of community care; Peter Tyrer 9-14

Computerised Axial Tomography (C.A.T.): Use of the C.A.T. head scanner in clinical psychiatry; J. K. A. Roberts and W. A. Lishman 152-158

'Confused': Doctors and nurses use of the word 'confused'; C. J. Simpson (Brief report) $\quad 441-443$

Coronary Artery: Psychosocial outcome after coronary artery by-pass surgery; Christopher Bass 526-532

Corrections: Clarification and assessment of a method of psychotherapy; David Goldberg et al (144, 567-575) 450

Evaluating the teaching of a method of psychotherapy; G. P. Maguire et al (144, 575-580) 450

Neuroleptic malignant syndrome; Gerard Addonizio and Virginia Susman (145, 556-557) (C) 672

Prediction of response to ECT (June 1984, 144, 670); John M. Eagles 219

Psychophysiological responses of schizophrenic patients to high and low expressed emotion relatives; David Sturgeon (July 1984, 145, 62-69) 338

Day hospitals: Comparative evaluations of two psychiatric day hospitals; Derek Milne 533-537

Impact of psychogeriatric day hospital care on the patient's family; C. J. Gilleard et al $487-492$

Scottish survey of chronic day-patients; Robin G. McCreadie et al $626-630$

Delusions: ECT, dopamine and delusions; Stephen J. Cooper and David J. King (C) 555

Rock and roll delusions; Jeffry Glass and Tom G. Campbell (C) 95-96. A. J. Robinson (C) 672

Dementia: Clinical dementia rating; Leonard Berg (C) 339

DST in dementia; B. Mahendra (C) $669-670$

Genetics, ageing and dementia; A. F. Wright and L. J. Whalley 20-38

Nominal dysphasia and the severity of senile dementia; $M$. Skelton-Robinson and S. Jones 168-171 


\section{SUBJECT INDEX}

Reversible dementia and depression; B. Mahendra (C) 213. John Colgan (C) 213-214. Alberto Spagnoli and Paul Williams (C) $\quad 339-340$

Value of P300 event-related potentials in the differential diagnosis of dementia; J. P. J. Slaets and C. Fortgens 652-656

Depersonalisation: Relaxation and depersonalisation; W. D. Fewtrell (C) 217

Depression, see also Affective Disorders. Anorexia nervosa and depression-reconsidering diagnostic criteria; Alan B. Levy and Katherine N. Dixon (C) 92-93

Breakdown of perceptual defence?; Mary Powell and David R. Hemsley 358-362

Classification and diagnosis of depression in school phobia; Israel Kolvin et al $\quad 347-357$

Cognitive-behaviour therapy for depression: problems and perspectives; J. Mark G. Williams (Review article) 254 262

Comparison of pharmacological treatment response between situational and non-situational depressions; Michael J. Garvey et al 363-365

Depression and affect-taden words; Andrew Firestone (C) 447

Depressive symptoms in pregnancy; Ray Ancill and Sean Hilton (C) 446-447

DST in psychotic versus non-psychotic endogenous depression; Zoltan Rihmer et al 508-511

DST and REM sleep in patients with major depressive disorder; Julian Mendlewicz et al 383-388

Drug combinations for chronic depression; Peter M. Graham (C) 214

Evaluation of cognitive-behaviour therapy for depression in patients with multiple sclerosis; Nora $\mathrm{A}$. Larcombe and Peter H. Wilson 366-371

Marital intimacy and depression; E. M. Waring and David Patton 641-644

Reversible dementia and depression; B. Mahendra (C) 213. John Colgan (C) 213-214. Alberto Spagnoli and Paul Williams (C) 339-340

Use of memory tests in differentiating organic disorder from depression; Anthony K. Coughlan and Susan E. Hollows 164-167

Validity of actometer and speech activity measures in the assessment of depressed patients; Hamish P. D. Godfrey and Robert G. Knight 159-163

Weight loss and the DST; Alec Coppen et al (Brief report) $\quad 88-90$

Desipramine: Effects of desipramine treatment upon central adrenoceptor function in normal subjects; T. H. Corn et al $139-145$

Dexamethasone Suppression Test (DST): Clinical use of the DST in a psychogeriatric population; Ian G. McKeith 389-393

Depression, weight loss and the DST: Alec Coppen et al (Brief report) 88-90

DST and REM sleep in patients with major depressive disorder; Julien Mendlewicz et al 383-388

DST and its relationship to psychiatric diagnosis, symptoms and treatment outcome; Helmfried E. Klein et al 591-599

DST and response to antidepressant drugs; Louise Braddock (C) $\quad 448-449$
DST in dementia; B. Mahendra (C) 669-670

DST in mania: prolonged suppression?; B. Bhadrinath et al (C) $555-556$

DST in psychotic versus non-psychotic endogenous depression: Zoltan Rihmer et al 508-511

Different categories of response; P.C.W. Bowie (C) 218219

Limited utility of the DST for the diagnostic process in psychiatry; M. Berger et al 372-382

Diabetes Mellitus: Neuropsychological function in diabetic patients with neuropathy; J. S. Lawson et al 263-268

Psychiatric aspects of diabetes mellitus; D. H. C. Surridge $e t$ al 269-276

Diagnosis: Classification and diagnosis of depression in school phobia; Israel Kolvin et al $\quad 347-357$

DST and its relationship to psychiatric diagnosis, symptoms and treatment outcome: Helmfried E. Klein et al 591-599

Limited utility of the DST for the diagnostic process in psychiatry; M. Berger et al 372-382

Value of P300 event-related potentials in the differential diagnosis of dementia; J. P. J. Slaets and C. Fortgens $652-656$

Diazepam: Relief of diazepam-withdrawal syndrome by shoplifting; Jeremy Coid (Brief report) 552-554

Diet: Dietary vitamin $B_{12}$ deficiency; Frank Rawlinson and John M. Eagles (C) 671

Dominance: Motor and sighting dominance in chronic schizophrenics: relationship to social competence, age at first admission and clinical course; Edward L. Merrin 401-406

Dopamine: ECT, dopamine and delusions; Stephen J. Cooper and David J. King (C) 555

Down's Syndrome: Anorexia nervosa in Down's syndrome; D. J. Cottrell and A. H. Crisp (Case report) 195-196

Nutritional aspects of Down's syndrome with special reference to the nervous system; Peter E. Sylvester 16th Blake Marsh lecture) $115-120$

Dreams after amputation; Larry Burd (C) 448. Alistair J. Macdonald (C) 669. James E. B. Lindesay (C) 669

Drugs see also Anticholinergics, Antidepressants, Monoamines and Neuroleptics

see also Benzhexol (Trihexyphenidyl), Clomipramine, Clonidine, Clorgyline, Desipramine, Dexamethasone, Haloperidol, Lithium, Mianserin, Testosterone, Warfarin and Zetidoline

Alcohol and sedative drug use in neurotic out-patients; D. S. Samarasinghe et al $\quad 45-48$

Combinations for chronic depression; Peter M. Graham (C) 214

DST and response to antidepressant drugs; Louise Braddock (C) 448-449

Drugs and suicide attempts in Benin City, Nigeria; Adego E. Eferakeya 70-73

Prescribing psychotropic drugs; Neil L. Holden (C) 93-94

Survey of prescribing of psychotropic drugs in a Birmingham psychiatric hospital; Stephen Edwards and Vinod Kumar 502-507

Dysphasia: Nominal dysphasia and the severity of senile dementia; M. Skelton-Robinson and S. Jones 168-171 


\section{SUBJECT INDEX}

Ekbom Syndrome: Co-existence of the Capgras and Ekbom syndromes; Jo-Ann McLaughlin and Andrew Sims (Brief report) 439-441

Elderly see also Old Age and Psycho-geriatric Patients:

Emotional distress amongst the supporters of the elderly mentally infirm; C. J. Gilleard et al 172-177

Family therapy with the elderly mentally ill. Some strategies and techniques; Lawrence Ratna and Jill Davis 311-315

Electro-convulsive Therapy (ECT): Autonomic monitor for ECT; J. M. Watkins-Pitchford and F. Reynolds (Brief report) 551-554

Dopamine and delusions; Stephen J. Cooper and David J. King (C) 555

Memory under three different waveforms of ECT; C. R. Shawcross (C) 95

Perceptual learning with right unilateral versus bilateral ECT; Walter F. Daniel et al $394-400$

Prediction of response to ECT (June 1984, 144, 670) (Correction) 219

Predictors of response to real and simulated ECT; David J. Weeks (C) 336. Reply; T. J. Crow and Eve C. Johnstone (C) $336-337$

Spontaneous second fit after ECT; A. James and D. Simpson (C) $337-338$

Electro-encephalogram (EEG) Value of P300 event-related potentials in the differential diagnosis of dementia; J. P. J. Slaets and C. Fortgens $\quad 652-656$

Schizophrenia and spectral analysis of the visual evoked potential; J. W. Jutai et al 496-501

Emotional Distress amongst the supporters of the elderly mentally infirm; C. J. Gilleard et al 172-177

Exe Vale Hospital: Suicides in Exe Vale Hospital, 1972-1981; G. E. Langley and N. N. Bayatti (Symposium) 463-467

Expressed Emotion: Psychophysiological assessment of expressed emotion in schizophrenia. A case example; Nicholas Tarrier and Christine Barrowclough (Brief report) 197-200

Psychophysiological responses of schizophrenic patients to high and low expressed emotion relatives: a follow-up study; David Sturgeon et al 62-69. Correction 338

Family see also Parents, Relatives and Supporters: Happy families?; J. M. Heron and R. F. Leheup 136-138

Impact of psychogeriatric day hospital care on the patient's family; C. J. Gilleard et al 487-492

Study of bipolar II disorder; W. Coryell et al 49-54

Therapy with the elderly mentally ill. Some strategies and techniques; Lawrence Ratna and Jill Davis 311-315

Females: Anorexia nervosa; long-term outcome in 50 female patients; Anne Hall et al $\quad 407-413$

Day-to-day mood changes after childbirth: further data; $\mathbf{R}$. E. Kendell et al $\quad 620-625$

Depressive symptoms and pregnancy; Ray Ancill and Sam Hilton (C) $\quad 446-447$

Fiji: Suicide in Fiji; a preliminary study; Ruth $H$ Haynes 433-438

Food Allergy: Psychiatric study of patients with supposed food allergy; Keith J. B. Rix et al 121-126
General Practice: Brief psychotherapy in family practice; Henry Brodarty and Gavin Andrews (C) 97

General practice psychiatric clinics, impact on psychiatric services; Peter Tyrer et al $\quad$ 15-19

Psychiatric clinics in general practice, an extension of community care; Peter Tyrer 9-14

Genetics, ageing and dementia; A. F. Wright and L. J. Whalley 20-38

Gestalt Therapy in theory and in practice; Richard Tillett (Annotation) 231-235

Gosse, Edmund: Hugh L. Freeman (Reading about) 667668

Hallucinations: Psychotic children with hallucinations; M. E. Garralda 74-77

Haloperidol: Case report; psychomotor status-like episodes under haloperidol treatment; Y. Kamcner and H. Munitz (Brief report) 87-88

Zetidoline, a new antipsychotic. First controlled trial in acute schizophrenia; T. Silverstone et al 294-299

Headache: Investigation of the aetiology of chronic headache: the role of headache models; Ira D. Turkat et al (Brief report) $665-666$

Heat Stroke: Neuroleptic malignant syndrome and heat stroke; Gerard Addonizio and Virginia Susman (C) 556557. Correction 672

High Buildings: Jumping from a great height; $\mathbf{G}$. Roberts and D. Ellison (C) 670-671

Suicide in high buildings; Paula H. Salmons (Symposium) 469-472

Hospitals see also Day Hospitals: Assessment of suicide risk in psychiatric in-patients; H. G. Morgan and Pamela Priest (Symposium) 467-469

Injuries in a psychiatric hospital; Antonio A. Rizzoli (C) 94

Psychiatric hospital admissions in Bristol. I. Geographical and ethnic factors; $B$. Ineichen et al 600-604

II. Social and clinical aspects of compulsory admission; Glynn Harrison et al 605-611

Schizophrenic patients discharged from hospital-a followup study; Eve C. Johnstone et al 586-590

Special characteristics of suicide in hospital in-patients; J. L. Crammer (Symposium) 460-463

Suicide in Exe Vale Hospital, 1972-1981; G. E. Langley and N. N. Bayatti (Symposium) 463-467

Suicide in high buildings; Paula H. Salmons (Symposium) $469-472$

Survey of prescribing of psychotropic drugs in a Birmingham psychiatric hospital; Stephen Edwards and Vinod Kumar 502-507

Survey of unexpected deaths among psychiatric in-patients and ex-patients; Susan Shaw and Andrew Sims (Symposium) $\quad 473-476$

Why are the mentally handicapped admitted to hospital? A ten-year survey; G. Carter 283-288

Hyperparathyroidism and paranoid psychosis. Case report and review of the literature; Renato D. Alarćon and José A. Franceschini (Review article) $\quad 477-486$

Hyperthyroidism: Agoraphobia and hyperthyroidism; T. H. Turner (C) 215-216 


\section{SUBJECT INDEX}

Hyperventilation Syndrome: Pilot study on the effectiveness of treatment: A. R. Kraft and C. A. L. Hoogduin 538542

Hypocholesterolsemia in cancer and other causes of death in the mentally handicapped; J. Jancar et al 59-61

Hypothalamic-Pituitary-Gonadal (HPG) Dysfunction: Is there HPG dysfunction in paedophilia?; Gary R. Gaffney and Fred S. Berlin 657-660

'Idealisation': Note on two important aspects of Kleinian theory 'projective identification' and 'idealisation': Philippe M. Ployé 55-58

In the beginning; Geoff Layton (C) 338

Immunoglobulins: Serum immunoglobulin concentrations in patients admitted to an acute psychiatric in-patient service; Lynn E. DeLisi et al (Brief report) 661-665

Informed Consent; Max Hamilton (C) 449

Injuries in a psychiatric hospital; Antonio P. Rizzoli (C) 94

Italy: High-dose neuroleptics in Italy; Cornelia Thiels (C) 212. Reply; Gianni Tognoni and Paola Bollini (C) 212-213

Kleinian Theory: Note on two important aspects of Kleinian theory 'projective identification' and 'idealisation'; Philippe M. Ployé 55-58

In the beginning; Geoff Layton (C) 338

Koro; Madhu H. Padi (C) 558-559

Kora and psychosis; P. C. Ang and M. P. I. Weller (Brief report) 335

Koro-like symptom in a non-Chinese subject; G. E. Berrios and S. J. Morley (Brief report) 331-334

Learning: Perceptual learning with right unilateral versus bilateral electroconvulsive therapy; Walter F. Daniel et al $394-400$

Lectures: Clinical medicine: its challenges and its responsibilities; Sir John Walton (57th Maudsley lecture, November 1983) 1-8

Nutritional aspects of Down's syndrome with special reference to the nervous system; Peter E. Sylvester (16th Blake Marsh lecture) 115-120

Psychiatry in jeopardy; Kenneth Rawnsley (Presidential Address, July 1984) 573-578

Psychosis in bipolar and unipolar affective illness with special reference to schizo-affective disorder; George Winokur (November 1983) 236-242

Lithium effects in schizophrenia; Raymond Faber (C) 91. Reply; F. P. Zemlan et al (C) 91

Mortality of a lithium-treated population; Beverley Norton and Lawrence J. Whalley 277-282

Madness: Monoamines and madness: Timothy G. Dinan (C) $96-97$

Males: Outcome of anorexia nervosa in males; Tom Burns and A. H. Crisp 319-325

Testosterone therapy for low sexual interest and erectile dysfunction in men: a controlled study; Ronan $0^{\circ}$ Carroll and John Bancroft 146-151

TRH response pattern in adolescent schizophrenic males; Lawrence DeMilio 649-651

Malignancy, see also Cancer: Smoking and malignancy in schizophrenia; E. Masterson and B. O'Shea 429-432

Mania: DST in mania: prolonged suppression?; B. Bhadrinath et al (C) 555-556
Marital Intimacy and depression; E. M. Waring and David Patton 641-644

Medical Subject Headings: Participation and Medical Subject Headings; C. Norris (C) 99

Medicine: Clinical medicine: its challenges and its responsibilities; Sir John Walton (57th Maudsley lecture, November 1983) $1-8$

Memory under three different waveforms of ECT; C. R. Shawcross (C) 95

Use of memory tests in differentiating organic disorder from depression; Anthony K. Coughlan and Susan E. Hollows 164-167

Menstrual Cycle: Real menstrual cycle; Doreen Asso (C) 559

Mental Disorders: Disorders with overvalued ideas; P. J. McKenna (Review article) $\quad 579-585$

Emotional distress amongst the supporters of the elderly mentally infirm; C. J. Gilleard et al 172-177

Family therapy with the elderly mentally ill; Lawrence Ratna and Jill Davis 311-315

How many psychiatric patients in prison?; Jeremy Coid 78 86

Mental changes resulting from subdural haematoma; Donald W. Black (Brief report) 200-203

Monoamines and madness; Timothy G. Dinan (C) 96-97

Mental Handicap: Hypocholesterolaemia in cancer and other causes of death in the mentally handicapped; J. Jancar $e t$ al 59-61

Natural history of behavioural symptoms among severely and profoundly mentally retarded patients; A. H. Reid et al 289-293

Why are the mentally handicapped admitted to hospital? A ten-year survey; G. Carter 283-288

Mianserin and warfarin: R. K. Shelley (C) 97-98. Donald C. Forster (C) 449

Mitral Valve Prolapse and anxiety disorders; Michael P. Chan et al (C) 216-217. No longer an enigma; Christopher Bass (C) $447-448$

Monoamines and madness; Timothy G. Dinan (C) 96-97

Mood changes in bulimia nervosa; E. C. Johnson-Sabine et al $512-516$

Day-to-day mood changes after childbirth: further data; $\mathbf{R}$. E. Kendell et al $620-625$

Morbidity: How many psychiatric patients in prison?; Jeremy Coid 78-86

Impact of political violence on mild psychiatric morbidity in Northern Ireland; Ed Cairns and Ronnie Wilson 631-635

Mortality of a lithium-treated population; Beverley Norton and Lawrence J. Whalley $277-282$

Hypocholesterolaemia in cancer and other causes of death in the mentally handicapped; J. Jancar et al 59-61

Mother-child Relations: Rejection of a child by his mother successfully treated after three years; I. F. Brockington and E. Brierley $316-318$

Multiple Sclerosis: Evaluation of cognitive-behaviour therapy for depression in patients with multiple sclerosis; Nora A. Larcombe and Peter $\mathrm{H}$. Wilson 366-371

Nervous System: Nutritional aspects of Down's syndrome with special reference to the nervous system; Peter E. Sylvester (16th Blake Marsh lecture) $\quad$ 115-120 


\section{SUBJECT INDEX}

Neuroleptic Malignant Syndrome: T. Hari Singh (C) 98. Dinesh Bhagra (C) 449

Neuroleptic malignant syndrome and heat stroke; Gerard Addonizio and Virginia Susman (C) 556-557. Correction 672

Treatment of neuroleptic malignant syndrome; Kurri Reddi (C) $217-218$

Neuroleptics: High-dose neuroleptics; J. Zalokar (C) 94-95

High-dose neuroleptics in Italy; Cornelia Thiels (C) 212. Reply; Gianni Tognoni and Paola Bollini (C) 212-213

Neuropsychiatric Disorders: Modern or traditional? A study of treatment preference for neuropsychiatric disorders in Botswana; Jeremy R. Dale and David I. Ben-Tovim 187192

Neuropsychology: Neuropsychological function in diabetic patients with neuropathy; J. S. Lawson et al 263-268

Neurotic Disorders: Alcohol and sedative drug use in neurotic out-patients; D. S. Samarasinghe et al 45-48

Psychiatric study of patients with supposed food allergy; Keith J. B. Rix et al 121-126

New York City: AIDS in New York City with particular reference to the psycho-social aspects; Neil Deuchar 612619

Nigeria: Drugs and suicide attempts in Benin City, Nigeria; Adego E. Eferakeya 70-73

Noradrenaline and tardive dyskinesia; R. Sandyk and M. A Gillmann (C) 217

Northern Ireland: Impact of political violence on mild psychiatric morbidity in Northern Ireland; Ed Cairns and Ronnie Wilson 631-635

Nutrition: Nutritional aspects of Down's syndrome with special reference to the nervous system; Peter E. Sylvester (16th Blake Marsh lecture) $\quad 115-120$

Obsessive Compulsive Disorder: Psychophysiological changes during pharmacological treatment of patients with obsessive compulsive disorder; Theodore P. Zahn et al 39-44

Old Age see also Elderly and Psychogeriatric Patients: Schizophrenia in old age (Late paraphrenia); P. S. Grahame 493-495

Organic Mental Disorders: Mental changes resulting from subdural haematoma; Donald W. Black (Brief report) 200-203

Use of the C.A.T. head scanner in clinical psychiatry; J. K. A. Roberts and W. A. Lishman 152-158

Use of memory tests in differentiating organic disorder from depression; Anthony K. Coughlan and Susan E. Hollows 164-167

Outcome: Anorexia nervosa: long-term outcome in 50 female patients; Anne Hall et al $\quad 407-413$

Anorexia nervosa in males; Tom Burns and A. $\mathrm{H}$. Crisp 319-325

Comparative evaluation of two psychiatric day hospitals; Derek Milne 533-537

DST and its relationship to psychiatric diagnosis, symptoms and treatment outcome; Helmfried E. Klein et al 591-599

Long-term outcome of bereavement; Tom Lundin 424-428

Psychosocial outcome after coronary artery by-pass surgery; Christopher Bass 526-532
Overvalued Ideas: Disorders with overvalued ideas; P. J. McKenna (Review article) $\quad 579-585$

Paedophilia: Is there hypothalamic-pituitary-gonadal dysfunction in paedophilia? A pilot study; Gary R. Gaffney and Fred S. Berlin 657-660

Paraphrenia: Schizophrenia in old age (Late paraphrenia); P. S. Grahame 493-495

Parents, see also Family, Relatives and Supporters

Psychophysiological assessment of expressed emotion in schizophrenia-a case example; Nicholas Tarrier and Christine Barrowclough (Brief report) 197-200

Participation and Medical Subject Headings; C. Norris (C) 99

Perception: Depression; a breakdown of perceptual defence?; Mary Powell and David R. Hemsley 358-362

Perceptual learning with right unilateral versus bilateral electroconvulsive therapy; Walter F. Daniel et al 394-400

Persuasion and Healing: J. D. Frank; Mark Aveline (Books reconsidered) 207-211

Phantom Head; Paul Divall and Matthew Jelley (C) 449 450

Self-shooting of a phantom head; David Ames (Case report) 193-194

Phobic Disorders: Classification and diagnosis of depression in school phobia; Israel Kolvin et al 347-357

Predictors of response to real and simulated ECT; David J. Weeks (C) 336. Reply; T. J. Crow and Eve C. Johnstone (C) $\quad 336-337$

Pregnancy: Depressive symptoms and pregnancy; Ray Ancill and Sean Hilton (C) 446-447

Prescribing psychotropic drugs; Neil L. Holden (C) 93-94

Survey of prescribing of psychotropic drugs in a Birmingham psychiatric hospital; Stephen Edwards and Vinod Kumar 502-507

Prison: How many psychiatric patients in prison?; Jeremy Coid 78-86

Progressive Supranuclear Palsy: B. Das (C) 214-215

'Projective Identification': Note on two important aspects of Kleinian theory 'projective identification' and 'idealisation'; Philippe M. Ployé $55-58$

In the beginning; Geoff Layton (C) 338

Psychiatry in jeopardy; Kenneth Rawnsley (Presidential address, July 1984) 573-578

Psychogeriatric patients see also Elderly and Old Age

Clinical use of the DST in a psychogeriatric population; Ian G. McKeith 389-393

Fate of psychogeriatric patients; A. J. Williams (C) 96

Impact of psychogeriatric day hospital care on the patient's family; C. J. Gilleard et al 487-492

Psychomotor Disorders: Case report: psychomotor status-like episodes under haloperidol treatment; $Y$. Kaminer and $\mathbf{H}$. Munitz (Brief report) 87-88

Psychophysiology: Psychophysiological assessment of expressed emotion in schizophrenia-a case example; Nicholas Tarrier and Christine Barrowclough (Brief report) $197-200$

Psychophysiological changes during pharmacological treatment of patients with obsessive compulsive disorder; Theodore P. Zahn et al $\quad 39-44$ 


\section{SUBJECT INDEX}

Psychophysiological responses of schizophrenic patients to high and low expressed emotion relatives: a follow-up study: David Sturgeon et al 62-69. Correction 338

Psycho-social Aspects: AIDS in New York City with particular reference to the psycho-social aspects: Neil Deuchar 612-619

Psychosocial outcome after coronary artery by-pass surgery: Christopher Bass 526-532

Psychotherapy see also Cognitive Therapy, Gestalt Therapy, Persuasion and Healing, and Relaxation

Brief psychotherapy in family practice: Henry Brodaty and Gavin Andrews (C) 97

Classification and assessment of a method of psychotherapy; David Goldberg et al (144,567-575). Correction 450

Evaluating the teaching of a method of psychotherapy: G. P Maguire et al (144,575-580). Correction 450

Psychotic Disorders: DST in psychotic versus non-psychotic endogenous depression: Zoltán Rihmer et al 508-511

Hyperparathyroidism and paranoid psychosis. Case report and review of the literature: Renato D. Alarcón and José A. Franceschini (Review' article) 477-486

Koro and psychosis: P. C. Ang and M. P. I. Weller (Brief report) 335

Is there really a schizophrenia? The long-term course of psychotic phenomena: Luc Ciompi $636-640$

Psychosis in anorexia nervosa and bulimia; James I. Hudson et al $420-423$

Psychosis in bipolar and unipolar affective illness with special reference to schizo-affective disorder: George Winokur (Lecture. November 1983) 236-242

Psychotic children with hallucinations: M. E. Garralda 74 77

Re-evaluation of the viral hypothesis: is psychosis the result of retroviral integration at a site close to the cerebral dominance gene'?: Timothy J. Crow 243-253

P 300 Event-related Potentials: Value in the differential diagnosis of dementia: J. P. J. Slaets and C. Fortgens $652-656$

Rapid Eye Movement (REM): Dexamethasone suppression test and REM sleep in patients with major depressive disorder: Julien Mendlewicz et al 383-388

Rating: Clinical dementia rating: Leonard Berg (C) 339. Rating tardive dyskinesia; Thomas E. Barnes (C) 338

Reading About: Edmund Gosse; Hugh L. Freeman 667-668

Rehabilitation: Measurement of psychiatric rehabilitation status. A review of the needs and a new scale; James W. Affleck and Ralph J. McGuire 517-525

Rejection of a child by his mother successfully treated after three years: I. F. Brockington and E. Brierley 316-318

Relatives see also Family, Parents and Supporters

Psychophysiological responses of schizophrenic patients to high and low expressed emotion relatives: a follow-up study: David Sturgeon et al 62-69

Relaxation and depersonalisation; W. D. Fewtrell (C) 217

Retroviral Integration: Re-evaluation of the viral hypothesis: is psychosis the result of retroviral integration at a site close to the cerebral dominance gene?; Timothy J. Crow 243253
Review Articles: Cognitive-behaviour therapy for depression: problems and perspectives; J. Mark G. Williams 254-262

Disorders with over-valued ideas: P. J. McKenna 579-585

Hyperparathyroidism and paranoid psychosis. Case report and review of the literature: Renato D. Alarcón and José A. Franceschini $477-486$

Rock and roll delusions: Jeffry Glass and Tom G. Campbell (C) 95-96. A. J. Robinson (C) 672

Role Changes: Misinterpreting role changes as changes of person; P. F. Bolton (C) 445-446. Consultant Psychotherapist (C) 446

Schizo-affective Disorder: Psychosis in bipolar and unipolar affective illness with special reference to schizo-affective disorder; George Winokur (Lecture, November 1983) 236-242

Schizoid Personality in childhood: Lorna Wing (C) 444. Reply: Ann Cull et al (C) 444-445

Schizophrenia:-Is there really a schizophrenia? The longterm course of psychotic phenomena; Luc Ciompi 636640

Lithium effects in schizophrenia: Raymond Faber (C) 91 . Reply; F. P. Zemlan et al (C) 91

Motor and sighting dominance in chronic schizophrenics: relationship to social competence, age at first admission and clinical course: Edward L. Merrin 401-406

Past and present perceived attitudes of schizophrenics in relation to rehospitalization (March. 1984, 144, 263-269): B. Baker et al (C) (Addendum) 219

Psychophysiological assessment of expressed emotion in schizophrenia-a case example; Nicholas Tarrier and Christine Barrowclough (Brief report) 197-200)

Psychophysiological responses of schizophrenic patients to high and low expressed emotion relatives: a follow-up study: David Sturgeon et al 62-69. Correction 338

Schizophrenia in old age (Late paraphrenia); P. S. Grahame 493-495

Schizophrenia and spectral analysis of the visual evoked potential; J. W. Jutai et al 496-501

Schizophrenic patients discharged from hospital-a followup study; Eve C. Johnstone et al 586-590

Smoking and malignancy in schizophrenia: E. Masterson and B. O'Shea 429-432

TRH response pattern in adolescent schizophrenic males Lawrence DeMilio 649-651

Zetidoline, a new antipsychotic. First controlled trial in acute schizophrenia: T. Silverstone et al 249-299

School Phobia: Classification and diagnosis of depression in school phobia: Israel Kolvin et al 347-357

Scotland: Scottish survey of chronic day-patients; Robin G. McCreadie et al 626-630

Self-poisoning: Children who poison themselves. I. A clinical comparison with psychiatric controls 127-132. II. Prediction of attendance for treatment: E. A. Taylor and S. A. Stansfeld 132-135

Self-shooting of a phantom head: David Ames (Case report) 193-194

Sex Disorders: Review of Sexual Strands; Understanding and Treating Sexual Anomalies in Men, by F. E. Kenyon: R. Langevin (C) 672 


\section{SUBJECT INDEX}

Testosterone therapy for low sexual interest and erectile dysfunction in men: a controlled study; Ronan O'Carroll and John Bancroft 146-151

Shoplifting: Relief of diazepam-withdrawal syndrome by shoplifting; Jeremy Coid (Brief report) 552-554

Smoking and malignancy in schizophrenia; E. Masterson and B. O'Shea 429-432

Speech Activity: Validity of actometer and speech activity measures in the assessment of depressed patients; Hamish P. D. Godfrey and Robert G. Knight 159-163

Subdural Haematoma: Mental changes resulting from subdural haematoma; Donald W. Black (Brief report) 200 203

Suicide: Assessment of suicide risk in psychiatric in-patients; H. G. Morgan and Pamela Priest (Symposium) 463-467

Children who poison themselves. I. A clinical comparison with psychiatric controls 127-132. II. Prediction of attendance for treatment; E. A. Taylor and S. A. Stansfeld 132-135

Drugs and suicide attempts in Benin City, Nigeria; Adego E. Eferakeya 70-73

Jumping from a great height; G. Roberts and D. Ellison (C) 670-671

Special characteristics of suicide in hospital in-patients; J. L. Crammer (Symposium) 460-463

Suicide in Exe Vale Hospital, 1972-1981; G. E. Langley and N. N. Bayatti (Symposium) 463-467

Suicide in Fiji: a preliminary study; Ruth H. Haynes 433438

Suicide in high buildings; Paula H. Salmons (Symposium) $469-472$

Survey of unexpected deaths among psychiatric in-patients and ex-patients; Susan Shaw and Andrew Sims (Symposium) $469-472$

Supporters see also Family and Relatives

Emotional distress amongst the supporters of the elderly mentally infirm; C. J. Gilleard et al 172-177

Symposium on suicide in hospital; edited by J. L. Crammer $\quad 459-476$

Tardive Dyskinesia: Effect of anticholinergics on tardive dyskinesia. A controlled discontinuation study; W. Greil et al 304-310.

Noradrenaline and tardive dyskinesia; R. Sandyk and M. A. Gillman (C) 217

Rating tardive dyskinesia; Thomas R. E. Barnes (C) 338

Testosterone therapy for low sexual interest and erectile dysfunction in men: controlled study; Ronan O'Carroll and John Bancroft 146-151

Thyrotropin Releasing Hormone (TRH): Response pattern in adolescent schizophrenic males; Lawrence DeMilio 649 651

Treatment: Approaches to the evaluation and treatment of rapid-cycling affective illness; Peter $P$. Roy-Byrne et al $543-550$

Changes occurring in appetite and weight during short-term antidepressant treatment; Brian Harris et al $645-648$

Comparison of pharmacological treatment response between situational and non-situational depressions; Michael J. Garvey et al 363-365
Hyperventilation syndrome. A pilot study on the effectiveness of treatment; A. R. Kraft and C. A. L. Hoogduin 538-542

Modern or traditional? A study of treatment preference for neuropsychiatric disorders in Botswana; Jeremy R. Dale and David I. Ben-Tovim 187-192

Trihexyphenidyl (Benzhexol): Study of benzhexol abuse; John A. Crawshaw and Paul E. Mullen 300-303

Triplets: Anorexia nervosa: a study of 34 twin pairs and one set of triplets; A. J. Holland et al 414-419

Twins: Anorexia nervosa: a study of 34 twin pairs and one set of triplets; A. J. Holland et al 414-419

Violence: The impact of political violence on mild psychiatric morbidity in Northern Ireland; Ed Cairns and Ronnie Wilson 631-635

Viral Hypothesis: Re-evaluation of the viral hypothesis: is psychosis the result of retroviral integration at a site close to the cerebral clominance gene?; Timothy J. Crow 243-253

Visual Evoked Potential: Schizophrenia and spectral analysis of the visual evoked potential; J. W. Jutai et al 496-501

Vitamins: Dietary vitamin $B_{12}$ deficiency; Frank $B$. Rawlinson and John M. Eagles (C) 671

Warfarin: Mianserin and warfarin; R. K. Shelley (C) 9798. Donald C. Forster (C) 449

Weight: Changes occurring in appetite and weight during short-term antidepressant treatment; Brian Harris et al $645-648$

Depression, weight loss and the DST; Alec Coppen et al (Brief report) 88-90

Withdrawal Syndrome: Relief of diazepam-withdrawal syndrome by shoplifting; Jeremy Coid (Brief report) $552-$ 554

Words: Depression and affect-laden words; Andrew Firestone (C) 447

Doctors and nurses use of the word 'confused' C. J. Simpson (Brief report) 441-442

Zetidoline, a new antipsychotic. First controlled trial in acute schizophrenia; T. Silverstone et al 294-299

Zimbabwe: Anorexia nervosa in a black Zimbabwean; $T$. Buchan and L. D. Gregory 326-330

\section{PART II-CONTRIBUTORS}

Adams, Henry E. - see Turkat, Ira D.

Addonizio, Gerard (C) 556

Affleck, James W. and McGuire, Ralph J. The measurement of psychiatric rehabilitation status. A review of the needs and a new scale 517

Alarcón, Renato D. and Franceschini, José A. Hyperparathyroidism and paranoid psychosis: case report and review of the literature (Review article) 477

Ames, David. Self-shooting of a phantom head (Case report) 193

Ancill, Ray (C) 446

Andreasen, N.-see Coryell, $\mathbf{w}$. 


\section{INDEX TO CONTRIBUTORS}

Ang, P. C. and Weller, M. P. I. Koro and psychosis (Brief report) 335

Arato, Mihály-see Rihmer, Zoltán

Asso, Doreen (C) 559

Aveline, Mark. Books Reconsidered: J. D. Frank's Persuasion and Healing 207

Baker, B. (C) 219

Ballinger, B. R. - see Reid, A. H.

Bancroft, John-see O'Carroll, Ronan

Barnes, Thomas R. E. (C) 338

Barrowclough, Christine-see Tarrier, Nicholas

Bass, Christopher (C) 447

Psychosocial outcome after coronary artery by-pass surgery 526

Bayatti, N. N.-see Langley, G. E.

Belford, H.-see Gilleard, C. J.

Bender, Wolfram-see Klein, Helmfried, E.

Bentley, Stephen J.--see Rix, Keith J. B.

Ben-Tovim, David I. - see Dale, Jeremy R.

Berg, Leonard (C) 339

Berger, M., Pirke, K.-M., Doerr, P., Krieg, J.-C. and Von Zerssen, D. The limited utility of the dexamethasone suppression test for the diagnostic process in psychiatry 372

Berkowitz, Ruth-see Sturgeon, David

Berlin, Fred S.-see Gafiney, Gary R.

Berney, Tom P. - see Kolvin, Israel

Berrios, G. E. and Morley, S. J. Koro-like symptom in a nonChinese subject (Brief report) 331

Bhadrinath, B. (C) 555

Bhate, Surya R.-see Kolvin, Israel

Bhugra, Dinesh (C) 449

Bird, C. E. - see Lawson, J. S.

-see Surridge, D. H. C.

Birkett, D. Peter (C) 95

Black, Donald W. Mental changes resulting from subdural haematoma (Brief report) 200

Bolton, P. F. (C) $\mathbf{4 4 5}$

Bowie, P. C. W. (C) 218

Braddock, Louise (C) 448

Brierley, E.-see Brockington, I. F.

Brockington, I. F. and Brierley, E. Rejection of a child by his mother: successfully treated after three years 316

Brodaty, Henry (C) 97

Brown, Linda M. (C) 558

Buchan, T.-see Gregory, L. D.

Burd, Larry (C) 448

Burns, Tom and Crisp, A. H. Outcome of anorexia nervosa in males 319

Cairns, Ed and Wilson Ronnie. The impact of political violence on mild psychotic morbidity in Northern Ireland 631

Carter, G. Why are the mentally handicapped admitted to hospital? A ten-year survey 283

-see Jancar, J.

Chan, Michael P. (C) 216

Checkley, S. A. - see Corn, T. H.

Ciompi, Luc. Is there really a schizophrenia? The long-term course of psychotic phenomena 636
Coid, Jeremy. How many psychiatric patients in prison? 78

Relief of diazepam-withdrawal syndrome by shoplifting (Brief report) 552

Colgan, John (C) 213

Connolly, J. F.-see Jutai, J. W.

Consultant Psychotherapist. Anonymous (C) 446

Cooper, Stephen J. (C) 555

Coppen, Alec, Harwood, Janet and Wood, Keith. Depression, weight loss and the dexamethasone suppression test (Brief report) 88

Corn, T. H., Thompson, C. and Checkley, S. A. Effects of desipramine treatment upon central adrenoceptor function in normal subjects 139

Coryell, W., Endicott, J., Reich, T., Andreasen, N. and Keller, M. A family study of bipolar II disorder 49

Cottrell, D. J. and Crisp, A. H. Anorexia nervosa in Down's Syndrome (Case report) 195

Coughlan, Anthony K. and Hollows, Susan E. Use of memory tests in differentiating organic disorder from depression 164

Cox, J. L. - see Kendell, R. E.

Crammer, J. L. The special characteristics of suicide in hospital in-patients (Symposium on Suicide in Hospital) $\mathbf{4 6 0}$

Crawshaw, John A. and Mullen, Paul E. A study of benzhexol abuse 300

Crisp, A. H.-see Burns, Tom

-see Cottrell, D. J.

- see Holland, A. J.

Crovitz, Herbert F. - see Daniel, Walter F.

Crow, Timothy J. A re-evaluation of the viral hypothesis: Is psychosis the result of retroviral integration at a site close to the cerebral dominance gene? 243

- see Johnstone, Eve C.

-see (C) 336

Cull, A. (C) 444

Dale, Jeremy R. and Ben-Tovim, David I. Modern or traditional? A study of treatment preference for neuropsychiatric disorders in Botswana 187

Daniel, Walter F., Crovitz, Herbert F. and Weiner, Richard D. Perceptual learning with right unilateral versus bilateral electroconvulsive therapy 394

Das, B. (C) 214

Davis, Jill-see Ratna, Lawrence

DeLisi, Lynn E., King, A. Catherine and Targum, Steven. Serum immunoglobulin concentrations in patients admitted to an acute psychiatric in-patient service (Brief report) 661

Demeter, Erzsébet-see Rihmer, Zoltán

De Milio, Lawrence. TRH response pattern in adolescent schizophrenic males 649

Deuchar, Neil. AIDS in New York City with particular reference to the psycho-social aspects 612

Dinan, Timothy G. (C) 96

Divall, Paul (C) 449

Doerr, P.-see Berger, $M$.

Donald, M. W. - see Lawson, J. S.

-see Surridge, D. H. C.

Dubini, A.- see Silverstone, T. 


\section{INDEX TO CONTRIBUTORS}

Eastham, R. D.- see Jancar, J.

Edwards, Stephen and Kumar, Vinod. A survey of prescribing of psychotropic drugs in a Birmingham psychiatric hospital 502

Eferakaya, Adego E. Drugs and suicide attempts in Benin City, Nigeria 70

Endicott, J. - see Coryell, W.

Erdahl, D. L. Williams-see Lawson, J. S.

-see Surridge, D. H. C.

Faber, Raymond (C) 91

Fewtrell, W. D. (C) 217

Firestone, Andrew (C) 447

Forster, Donald C. (C) 449

Fortgens, C. - see Slaets, J. P. J.

Franceschini, José A.-see Alarcon, Renato D.

Freeman, Hugh. Reading About . . . Edmund Gosse 667

- see Silverstone, $T$.

Garmey, Gary R. and Berlin, Fred S. Is there hypothalamicpituitary-gonadal dysfunction in paedophilia? A pilot study 657

Garralda, M. E. Psychotic children with hallucinations 74

Garvey, Michael J., Schafier, Charles B. and Tuason, V. B. Comparison of pharmacological treatment response between situational and non-situational depressions 363

Gilleard, C. J., Belford, H., Gilleard, E., Whittick, J. E. and Gledhill, K. Emotional distress amongst the supporters of the elderly mentally infirm 172

- Gilleard, E. and Whittick, J. E. Impact of psychogeriatric day hospital care on the patient's family 487

Gilleard, E. - see Gilleard, C. J.

Glass, Jefiry (C) 95

Gledhill, K.-see Gilleard, C. J.

Godfrey, Hamish P. D. and Knight, Robert G. The validity of actometer and speech activity measures in the assessment of depressed patients 159

Gold, Aviva- see Johnstone, Eve C.

Graham, Peter M. (C) 214

Grahame, P. S. Schizophrenia in old age (late paraphrenia) 493

Gregory, L. D. and Buchan, T. Anorexia nervosa in a black Zimbabwean 326

Greil, W., Haag, H., Rossnagl, G. and Rüther, E. Effect of anticholinergics on tardive dyskinesia: A controlled discontinuation study 304

Gruzelier, J. H. - see Jutai, J. W.

György, Śndor-see Rihmer, Zoltan

Haag, H. - see Greil, W.

Hall, Anne, Slim, Enid, Hawker, Fiona and Salmond, Clare. Anorexia nervosa: long-term outcome in 50 female patients 407

- see Holland, A. J.

Hamilton, Max (C) 449

Harris, Brian, Young, John and Hughes, Bill. Changes occurring in appetite and weight during short-term antidepressant treatment 645
Harrison, Glynn, Ineichen, Bernard, Smith, Janet and Morgan, H. G. Psychiatric hospital admissions in Bristol. II. Social and clinical aspects of compulsory admission 605

- see Ineichen, $B$.

Harwood, Janet-see Coppen, Alec

Hawker, Fiona-see Hall, Anne

Haynes, Ruth H. Suicide in Fiji: a preliminary study 433

Healy, Kevin (C) 93

Heather, B. B. - see Reid, A. H.

Hemsley, David R.-see Powell, Mary

Heron, J. M. and Leheup, R. F. Happy families? 136

Hirsch, S. R. - see Jutai, J. W.

Hoffman, Guy-see Mendlewicz, Julien

Holden, Neil L. (C) 93

Holland, A. J., Hall, A., Murray, R., Russell, G. F. M. and Crisp, A. H. Anorexia nervosa: a study of 34 twin pairs and one set of triplets 414

Hollows, Susan E.-see Coughlan, Anthony K.

Hoogduin, C. A. L. - see Kraft, A. R.

Hudson, James I., Pope, Harrison G., Jr. and Jonas, Jeffrey $M$. Psychosis in anorexia nervosa and bulimia 420

Hughes, Bill-see Harris, Brian

Ineichen, B., Harrison, G. and Morgan, H. G. Psychiatric hospital admissions in Bristol. I. Geographic and ethnic factors 600

- see Harrison, Glynn

Insell, Thomas R.-see Zahn, Theodore P.

James, A. (C) 337

Jancar, J., Eastham, R. D. and Carter, G. Hypocholesterolaemia in cancer and other causes of death in the mentally handicapped 59

Joffe, Russell T.-see Roy-Byrne, Peter P.

Johnson-Sabine, E. C., Wood, K. H. and Wakeling, A. Mood changes in bulimia nervosa 512

Johnstone, Eve C., Owens, David G. C., Gold, Aviva, Crow, Timothy J. and J. Macmillan, Fiona. Schizophrenia patients discharged from hospital: a follow-up study 586

Jonas, Jefirey M. - see Hudson, James I.

Jones, S. - see Skelton-Robinson, $M$.

Jutai, J. W., Gruzelier, J. H., Connolly, J. F., Manchanda, R. and Hirsch, S. R. Schizophrenia and spectral analysis of the visual evoked potential 496

Kaminer, Y. and Munitz, H. Case report: psychomotor status-like episodes under haloperidol treatment (Brief report) 87

Keller, M.-see Coryell, w.

Kendell, R. E., Mackenzie, W. E., West, C., McGuire, R. J. and Cox, J. L. Day-to-day mood changes after childbirth; further data 620

Kerkhofs, Myriam-see Mendlewicz, Julien

King, A. Catherine-see DeLisi, Lynn E.

Klein, Helmiried E., Bender, Wolfram, Mayr, Hermann, Niederschweiberer, Alois and Schmauss, Max. The DST and its relationship to psychiatric diagnosis, symptoms and treatment outcome 591

Knight, Robert G.- see Godfrey, Hamish P. D. 


\section{INDEX TO CONTRIBUTORS}

Kolvin, Israel, Berney, Tom P. and Bhate, Surya Classification and diagnosis of depression in school phobia 347

Kraft, A. R. and Hoogduin, C. A. L. The hyperventilation syndrome. A pilot study on the effectiveness of treatment 538

Krieg, J.-C.-see Berger, M.

Kuczmierczyk, Andrzej—see Turkat, Ira D.

Kuipers, Liz-see Sturgeon, David

Kumar, Vinod-see Edwards, Stephen

Langevin, R. (C) 672

Langley, G. E. and Bayatti, N. N. Suicides in Exe Vale Hospital, 1972-1981 (Symposium on Suicide in Hospital) 463

Larcombe, Nora A. and Wilson, Peter H. An evaluation of cognitive-behaviour therapy for depression in patients with multiple sclerosis 366

Lawson, J. S., Erdahl, D. L., Williams, Monga, T. N., Bird, C. E., Donald, M. W., Surridge, D. H. C. and Letemendia, F. J. J. Neuropsychological function in diabetic patients with neuropathy 263

-see Surridge, D. H. C.

Layton, Geoff (C) 338

Leff, Julian-see Sturgeon, David

Leheup, R. F. - see Heron, J. M.

Letemendia, F. J. J.- see Lawson, J. S.

-see Surridge, D. H. C.

Levine, S. - see Silverstone, T.

Levy, Alan B. (C) 92

Lindesay, James E. B. (C) 669

Linkowski, Paul-see Mendlewicz, Julien

Lishman, W. A. - see Roberts, J. K. A.

Lundin, Tom. Long-term outcome of bereavement 424

McCreadie, Robin, Robinson, Andrew D. and Wilson, A. Oliver A. The Scottish survey of chronic day-patients 626

Macdonald, Alastair J. (C) 669

McGuire, Ralph J.-see Affleck, James W.

-see Kendell, R. E

McKeith, Ian G. Clinical use of the DST in a psychogeriatric population 389

McKenna, P. J. Disorders with overvalued ideas (Review article) 579

Mackenzie, W. E.-see Kendell, R. E.

McLaughlin, Jo-Ann and Sims, Andrew. Co-existence of the Capgras and Ekbom syndromes (Brief report) 439

Macmillan, J. Fiona-see Johnstone, Eve C.

Mahendra, B. (C) 213,669

Manchanda, R.-see Jutai, J. W.

Marks, I. M.-see Samarasinghe, D. S.

Masterson, E. and O'Shea, B. Smoking and malignancy in schizophrenia 429

Mayr, Hermann-see Klein, Helmfried E.

Melvin, S. J. - see Reid, A. H.

Mendlewicz, Julien, Kerkhofs, Myriam, Hoffman, Guy and Linkowski, Paul. Dexamethasone suppression test and REM sleep in patients with major depressive disorder 383

Merrin, Edward L. Motor and sighting dominance in chronic schizophrenics 401
Milne, Derek. A comparative evaluation of two psychiatric day hospitals 533

Monga, T. N.-see Lawson, J. S.

- see Surridge, D. H. C.

Morgan, H. G. and Priest, Pamela. Assessment of suicide risk in psychiatric in-patients (Symposium on Suicide in Hospital) 467

- see Harrison, Glynn

- see Ineichen, $B$.

Morley, S. J. - see Berrios, G. E.

Mullen, Paul E.-see Crawshaw, John A.

Munitz, H.-see Kaminer, Y.

Murphy, Dennis L.-see Zahn, Theodore P.

Murray, R. - see Holland, A. J.

Nair, N. P. V. (C) 557

Niederschweiberer, Alois—see Klein, Helmfried E.

Norris, C. (C) 99

Norris, Beverley and Whalley, Lawrence J. Mortality of a lithium-treated population 277

O'Carroll, Ronan and Bancroft, John. Testosterone therapy for low sexual interest and erectile dysfunction in men: a controlled study 146

O'Shea, B. - see Masterson, E.

Owens, David G. C. - see Johnstone, Eve C.

Padi, Madhu H. (C) 558

Patton, David-see Waring, E. M.

Pearson, David J.—see Rix, Keith J. B.

Pirke, K.-M. $\rightarrow$ see Berger, M.

Ployé, Philippe M. A note on two important aspects of Kleinian theory: 'projective identification' and 'idealisation 55

Pope, Harrison G., Jr.-see Hudson, James I.

Post, Robert M. - see Roy-Byrne, Peter P.

Powell, Mary and Hemsley, David R. Depression: a breakdown of perceptual defence? 358

Priest, Pamela-see Morgan, H. G.

Pullen, G. P. (C) 671

Ratna, Lawrence and Davis, Jill. Family therapy with the elderly mentally ill: some strategies and techniques 311

Rawlinson, Frank (C) 671

Rawnsley, Kenneth. Psychiatry in jeopardy (Presidentia Address at the Annual Meeting of the Royal College of Psychiatrists, July 1984) 573

Reddi, Kurri (C) 217

Reich, T.-see Coryell, W.

Reid, A. H., Ballinger, B. R., Heather, B. B. and Melvin, S. J. The natural history of behavioural symptoms among severely and profoundly mentally retarded patients 289

Révai, Katalin-see Rihmer, Zoltán

Reynolds, F.- see Watkins-Pitchford, J. M.

Rihmer, Zoltán, Arató, Mihály, Szádoczyky, Erika, Révai, Katalin, Demeter, Erzsébet, György, Sandor and Udvarhelyi, Pál. The dexamethasone suppression test in psychotic versus non-psychotic endogenous depression 508

Rix, Keith J. B., Pearson, David J. and Bentley, Stephen J. A psychiatric study of patients with supposed food allergy 121 


\section{INDEX TO CONTRIBUTORS}

Rizzolio, Antonio A. (C) 94

Roberts, G. (C) 670

Roberts, J. K. A. and Lishman, W. A. The use of the C.A.T. head scanner in clinical psychiatry 152

Robinson, Andrew D.- see McCreadie, Robin

Robinson, A. J. (C) 672

Rossnagl, G.- see Greil, W.

Roy-Byrne, Peter P., Joffee, Russell T., Uhde, Thomas W. and Post, Robert M. Approaches to the evaluation and treatment of rapid-cycling affective illness 543

Russell, G. F. M. - see Holland, A. J.

Rüther, E.-see Greil, W.

Salmond, Clare—see Hall, Anne

Salmons, Paula H. Suicide in high buildings (Symposium on Suicide in Hospital) 469

Samarasinghe, D. S., Tilley, S. and Marks, I. M. Alcohol and sedative drug use in neurotic outpatients 45

Sandyk, R. (C) 217

Schaffer, Charles B. - see Garvey, Michael J.

Schmauss, Max-see Klein, Helmfried E.

Seivewright, Nicholas-see Tyrer, Peter

Shaw, Susan and Sims, Andrew. A survey of unexpected deaths among psychiatric in-patients and ex-patients (Symposium on Suicide in Hospital) 473

Shawcross, C. R. (C) 95

Shelley, R. K. (C) 97

Silverstone, T., Levine, S., Freeman, H. L. and Dubini, A. Zetidoline, a new antipsychotic: first controlled trial in acute schizophrenia 294

Sims, Andrew-see McLaughlin, Jo-Ann Shaw, Susan

Simpson, C. J. Doctors' and nurses' use of the word confused (Brief report) 441

Singh, T. Hari (C) 98

Skelton-Robinson, M. and Jones, S. Nominal dysphasia and the severity of senile dementia 168

Slim, Enid-see Hall, Anne

Slaets, J. P. J. and Fortgens, C. On the value of P300 eventrelated potentials in the differential diagnosis of dementia 6.52

Smith, Janet-see Harrison, Glynn

Spagnoli, Alberto (C) 339

Stansfeld, S. A.-see Taylor, E. A.

Sturgeon, David, Turpin, Graham, Kuipers, Liz, Berkowitz, Ruth and Leff, Julian. Psychophysiological responses of schizophrenic patients to high and low expressed emotion relatives: a follow-up study 62

Sturt, Elizabeth. Community care in Camberwell: a two-year follow-up of a cohort of long-term users 178

Surridge, D. H. C., Erdahl, D. L. Williams, Lawson, J. S., Donald, M. W., Monga, T. N., Bird, C. E. and Letemendia, F. J. J. Psychiatric aspects of diabetes mellitus 269

- see Lawson, J. S.

Sylvester, Peter E. Nutritional aspects of Down's syndrome with special reference to the nervous system. Based on the Sixteenth Blake Marsh Lecture $1982 \quad 115$

Szádoczky, Erika-see Rihmer, Zoltán

Targum, Steven-see De Lisi, Lynn E.
Tarrier, Nicholas and Barrowclough, Christine. Psychophysiological assessment of expressed emotion in schizophrenia-a case example (Brief reports) 197

Taylor, E. A. and Stansfeld, S. A. Children who poison themselves. I. A clinical comparison with psychiatric controls. II. Prediction of attendance for treatment 127

Thiels, Cornelia (C) 212

Thompson, Christopher. Circadian rhythms and psychiatry (Comments) 204

- see Corn, T. H.

Tillett, Richard. Gestalt therapy in theory and in practice (Annotation) 231

Tilley, S. - see Samarasinghe, D. S.

Tognoni, Gianni (C) 212

Tuason, V. B.-see Garvey, Michael J.

Turkat, Ira D., Kuczmierczyk, Andrzej R. and Adams, Henry E. An investigation of the aetiology of chronic headache: the role of headache models (Brief report) 665

Turner, T. H. (C) 215

Turpin, Graham-see Sturgeon, David

Tyrer, Peter. Psychiatric clinics in general practice: an extension of community care 9

Tyrer, P., Seivewright, Nicholas and Wollerton, Stanley. General practice psychiatric clinics: impact on psychiatric services 15

Udvarhelyi, Páł see Rihmer, Zoltán

Uhde, Thomas W.-see Roy-Byrne, Peter P.

von Zerssen, D.- see Berger, M.

Wakeling, A.- see Johnson-Sabine, E. C.

Walton, Sir John. Clinical medicine: its challenge and its responsibilities (The Fifty-seventh Maudsley Lecture) 1

Waring, E. M. and Patton, David. Marital intimacy and depression 641

Watkins-Pitchford, J. M. and Reynolds, F. Autonomic monitor for electro-convulsive therapy (Brief report) $\quad 551$

Weeks, David J. (C) 336

Weiner, Richard D.- see Daniel, Walter F.

Weller, M. P. I.-see Ang, P. C.

West, C.- see Kendell, R. E.

Whalley, L. J.-see Norton, Beverley

-see Wright, A. F.

Whittick, J. E.-see Gilleard, C. J.

Williams, A. J. (C) 96

Williams, J. Mark G. Cognitive-behaviour therapy for depression: Problems and perspectives (Review article) 254

Wilson, A. Oliver A.- see McCreadie, Robin

Wilson, Peter H. - see Larcombe, Nora A.

Wilson, Ronnie-see Cairns, Ed

Wing, Lorna (C) 444

Winokur, George. Psychosis in bipolar and unipolar affective illness with special reference to schizo-affective disorder (Lecture) 236

Wollerton, Stanley-see Tyrer, Peter

Wood, Keith-see Coppen, Alec 


\section{INDEX TO CONTRIBUTORS}

Wood, K. H. - see Johnson-Sabine, E. C.

Wright, A. F. and Whalley, L. J. Genetics, ageing and dementia 20

Young, John-see Harris, Brian
Zahn, Theodore, Insell, Thomas R. and Murphy, Dennis L. Psychological changes during pharmacological treatment of patients with obsessive compulsive disorder 39

Zalokar, J. (C) 94

Zemlan, F. P. (C) 91

\section{AFFECTIVE DISORDERS}

Ayd, Frank J., Jr. et al (Eds.). Affective Disorders Reassessed: 1983343

\section{ALCOHOLISM AND ADDICTION}

Grant, Marcus and Ritson, Bruce. Alcohol: The Prevention Debate 344

Heather, Nick and Robertson, Ian. Controlled Drinking 569

Hofmann, Frederick G. A Handbook on Drug and Alcohol Abuse: The Biomedical Aspects. 2nd edition 677

Isralowitz, Richard and Singer, Mark (Eds.). Adolescent Substance Abuse: A Guide to Prevention and Treatment 682

\section{BEREAVEMENT}

Stedeford, Averil. Facing Death: Patients, Families and Professionals 454

\section{CHILDREN, ADOLESCENTS AND FAMILIES}

Boston, Mary and Szur, Rolene (Eds.). Psychotherapy with Severely Deprived Children 109

Call, Justin D., Galenson, Eleanor and Tyson, Robert L. (Eds.). Frontiers of Infant Psychiatry 107

Cantwell, Dennis P. and Carlson, Gabrielle A. (Eds.). Affective Disorders in Childhood and Adolescence: An Update 107

Chazan, M., Laing, A. F., Jones, J., Harper, G. C. and Bolton, J. Helping Young Children with Behaviour Difficulties 106

Clarke, A. D. B. and Tizard, B. (Eds.). Child Development and Social Policy: The Life and Work of Jack Tizard 106

Davis, A., Richards, M. P. M. and Roberton, N. R. C. (Eds.). Parent-Baby Attachment in Premature Infants 683

Donaldson, Margaret, Grieve, Robert and Pratt, Chris (Eds.). Early Childhood Development and Education: Readings in Psychology 108

Fagin, Leonard and Little, Martin. The Forsaken Families: The Effects of Unemployment of Family Life 561

Golombek, Harvey and Garfinkel, Barry D. (Eds.). The Adolescent and Mood Disturbance 452

Hollingsworth, Charles E. (Ed.). Coping with Paediatric Illness 106

Pediatric Consultation Liaison Psychiatry 108

Lindsay, Geoff (Ed.). Problems of Adolescence in the Secondary School 453

McCubbin, Hamilton I. and Figley, Charles R. (Eds.). Stress and the Family: Vol. I: Coping with Normative Transitions 226

Miles, T. R. and Miles, Elaine. Help for Dyslexic Children 108

Miller, Derek. The Age Between: Adolescence and Therapy 45 Morawetz, Anita and Walker,
Single-Parent Families 452

Oliverio, Alberto and Zappella, Michele (Eds.). The Behavior of Human Infants 227

Parker, Gordon. Parental Overprotection: A Risk Factor in Psychosocial Development 561

Parkes, C. M. and Stevenson-Hinde, J. (Eds.). The Place of Attachment in Human Behaviour 560

Schaefer, Charles E., Briesmeister, James M. and Fitton, Maureen E. Family Therapy Techniques for Problem Behaviours of Children and Teenagers 455

Solnit, Albert J., Eissler, Ruth S. and Neubauer, Peter B. (Eds.). The Psychoanalytic Study of the Child. Vol. $38 \quad 451$

Steinhauer, Paul D. and Rae-Grant, Quentin (Eds.). Psychological Problems of the Child in the Family. 2nd edition 676

Treacher, Andy and Carpenter, John (Eds.). Using Family Therapy 453

\section{COMPUTERS AND VIDEO}

Heilveil, Ira. Video in Mental Health Practice 458

Schwartz, Marc D. Using Computers in Clinical Practice. Psychotherapy and Mental Health Applications 458

\section{COUNSELLING}

Janis, Irving L. Short-term Counselling. Guidelines based on Recent Research 111

\section{DEPRESSION}

Baldessarini, Ross J. Biomedical Aspects of Depression and its Treatment 110

Gilbert, Paul. Depression: From Psychology to Brain State 570

Korf, J. and Pepplinkhuizen, L. (Eds.). Depression: Molecular and Psychologically based Therapies: An Integrative View 110

Van Praag, H. M. and Mendlewicz, J. (Eds.). Advances in Biological Psychiatry. Vol. 10. Management of Depressions with Monoamine Precursors 682

\section{DIAGNOSIS, MANAGEMENT AND TREATMENT}

Back Pain Association. Low Back Pain and Industrial and Social Disablement 682

Basmajian, John V. (Ed.). Biofeedback: Principles and Practice for Clinicians, 2nd edition 678

Bowden, Charles L. and Burstein, Alvin G. (Eds.). Psychosocial Basis of Health Care (third edition) 677

Brena, Steven F. and Chapman, Stanley L. (Eds.). Management of Patients with Chronic Pain 100

Campbell, Alastair V. Moderated Love: A Theology of Professional Care 454

Duus, Peter. Topical Diagnosis in Neurology 679 


\section{INDEX TO CONTRIBUTORS}

Goldberg, Richard and Tull, Robert M. The Psychosocial Dimensions of Cancer: A Practical Guide for Health Care Providers 676

Langer, Ellen J. The Psychology of Control 345

Meichenbaum, Donald and Jarenko, Matt E. (Eds.). Stress Reduction and Prevention 343

Weintraub, Michael I. Hysterical Conversion Reactions: A Clinical Guide to Diagnosis and Treatment 219

Wilson, Barbara A. and Moffat, Nick (Eds.). Clinical Management of Memory Problems 456

\section{DSM III}

Akhtar, Salman (Ed.). New Psychiatric Syndromes: DSM-III and Beyond 224

Rapoport, Judith L. and Ismond, Deborah R. DSM-III Training Guide for Diagnosis of Childhood Disorders 452

Reid, William H. Treatment of the DSM-III Disorders 99

\section{EATING DISORDERS}

Darby, Padraig L., Garfinkel, Paul E., Garner, David M. and Coscina, Donald V. (Eds.). Anorexia Nervosa: Recent Development in Research 572

Wilson, C. Philip (Ed.). Fear of Being Fat: The Treatment of Anorexia Nervosa and Bulimia 109

\section{EPILEPSY}

Parsonage, Maurice, Grant, Richard H. E., Craig, Andrew G. and Ward, Arthur A., Jr. (Eds.). Advances in Epileptology. XIVth Epilepsy International Symposium 220

Porter, Roger J. Epilepsy: 100 Elementary Principles 684

\section{MEDICINE AND PSYCHIATRY}

Creed, Francis and Pfeffer, Jeremy M. (Eds.). Medicine and Psychiatry: A Practical Approach 100

Wise, T. N. and Freyberger, H. (Eds.). Advances in Psychosomatic Medicine-Volume II-Consultation Liaison Throughout the World 100

\section{MENTAL HEALTH}

Syer, John and Connolly, Christopher. Sporting Body, Sporting Mind. An Athlete's Guide to Mental Training 567

Upton, David. Mental Health Care and National Health Insurance: A Philosophy of and an Approach to Mental Health Care for the Future 101

\section{PSYCHOANALYSIS}

Anzieu, Didier. The Group and the Unconscious 680 Khan, M. Masud R. Hidden Selves: Between Theory and Practice in Psychoanalysis 346

\section{PSYCHOGERIATRICS}

Bergener, Manfred (Ed.). Geropsychiatric Diagnostics and Treatment 566

Hanley, Ian and Hodge, John (Eds.). Psychological Approaches to the Care of the Elderly 569

Holden, Una P. and Woods, Robert T. Reality Orientation: Psychological Approaches to the 'Confused' Elderly 457

Kay, David W. K. and Burrows, Graham D. (Eds.). Handbook of Studies on Psychiatry and Old Age 567
Smyer, Michael A. and Gatz, Margaret (Eds.). Mental Health and Aging: Programmes and Evaluations 681

\section{PSYCHOLOGY}

Adams-Webber, Jack and Mancuso, James C. (Eds.). Applications of Personal Construct Theory 568

Jung, C. G. (Recorded and edited by Jaffé, Aniela). Memories, Dreams, Reflections 220

Karas, Eric (Ed.). Current Issues in Clinical Psychology I. 680

Kyle, Jim and Woll, Bencie (Eds.). Language in Sign 225

Leary, Mark R. Understanding Social Anxiety 564

\section{PSYCHOPATHOLOGY}

Flor-Henry, Pierre and Gruzelier, John (Eds.). Laterality and Psychopathology 221

Flor-Henry, Pierre. Cerebral Basis of Psychopathology 341

Perris, C., Kemali, D. and Koukou-Lehmann, M. (Eds.). Neurophysiological Correlates of Normal Cognition and Psychopathology 565

\section{PSYCHOPHARMACOLOGY}

Burrows, Graham D., Norman, Trevor R. and Davies, Brian (Eds.). Drugs in Psychiatry. Vol. I: Antidepressants 678

Habig, Robert L. (Ed.). The Brain, Biochemistry, and Behaviour: Proceedings of the Sixth Arnold O. Beckman Conference in Clinical Chemistry 677

Evans, L., Eadie, M. J., Hollister, L. and Tyrer, J. H. Drug Use in Psychiatry 345

Lickey, Marvin E. and Gordon, Barbara. Drugs for Mental Illness: A Revolution in Psychiatry 679

Spiegel, Rene and Aebi, Hans-J. Psychopharmacology: An Introduction 565

\section{PSYCHOSEXUAL}

Draper, Katharine (Ed.). Practice of Psychosexual Medicine Hazelwood, Robert R., Dietz, Park Elliott and Burgess, Ann Wolbert. Autoerotic Fatalities 228

Kaplan, Helen Singer. The Evaluation of Sexual Disorders: Psychological and Medical Aspects 683

Lothstein, Leslie Martin. Female-to-Male Transsexualism. Historical, Clinical and Theoretical Issues 104

Ross, M. W. The Married Homosexual Man: A Psychological Study 103

Tunnadine, Prudence. The Making of Love 105

Wheatley, David (Ed.). Psychopharmacology and Sexual Disorders 103

\section{PSYCHOSURGERY}

Turner, E. A. Surgery of the Mind 675

\section{NEUROPSYCHIATRY AND NEUROPSYCHOLOGY}

Miczek, Klaus C. (Ed.). Ethopharmacology: Primate Models of Neuropsychiatric Disorders 563

Rutter, Michael (Ed.). Developmental Neuropsychiatry 562

Shah, Nandkumar S. and Donald, Alexander G. (Eds.). Psychoneuroendocrine Dysfunction 563 


\section{INDEX TO CONTRIBUTORS}

\section{SOCIAL PSYCHIATRY}

Jacobson, Gerald F. The Multiple Crises of Marital Separation and Divorce 342

Shepherd, Michael. The Psychosocial Matrix of Psychiatry: Collected Papers 227

\section{SOCIOLOGY AND SOCIAL WORK}

Brannen, Julia and Collard, Jean. Marriages in Trouble 104 Butler, Alan and Pritchard, Colin. Social Work and Mental Illness 112

Fisher, Mike, Newton, Clive and Sainsbury, Eric. Mental Health Social Work Observed 112

Lewis, Jerry M. and Looney, John G. The Long Struggle: Well-Functioning Working-Class Black Families 456

\section{SUICIDE}

Buie, Dan H. and Maltsberger, John T. The Practical Formulation of Suicide Risk 564

\section{THERAPIES}

Adamson, Edward. Art as Healing 684

Boudewyns, Patrick A. and Shipley, Robert H. Flooding and Implosive Therapy: Direct Therapeutic Exposure in Clinical Practice 110

Carroll, Douglas. Biofeedback in Practice 562

Craig, Kenneth D. and McMahon, Robert J. Advances in Clinical Behaviour Therapy 344

Hersen, Michel (Ed.). Outpatient Behaviour Therapy: A Clinical Guide 674

Horowitz, Mardi Jon. Image Formation and Psychotherapy 572

Kennard, David and Roberts, Jeff. An Introduction to Therapeutic Communities 458
Krueger, David W. Rehabilitation Psychology: A Comprehensive Textbook 571

Lambert, Michael J., Christensen, Edwin R. and DeJulio, Steven S. (Eds.). The Assessment of Psychotherapy Outcome 109

Lange, Alfred and Van Der Hart, Onno. Directive Family Therapy 344

Masterson, James F. Countertransference and Psychotherapeutic Technique: Teaching Seminars on Psychotherapy of the Borderline Adult 684

Oatley, Keith. Selves in Relation: An Introduction to Psychotherapy and Groups 570

Pilgrim, David (Ed.). Psychology and Psychotherapy: Current Trends and Issues 680

Shainberg, Diane. Healing in Psychotherapy: The Process of Holistic Change 572

Thompson, Andrew. Ethical Concerns in Psychotherapy and their Legal Implications $\mathbf{5 7 0}$

Wallace, Edwin R., IV. Dynamic Psychiatry in Theory and Practice 102

Warren, Bernie. Using the Creative Arts in Therapy 679

Williams, J. Mark G. The Psychological Treatment of Depression: A Guide to the Theory and Practice of Cognitive-Behaviour Therapy 678

Yalom, Irvin D. In Patient Group Psychotherapy 571

\section{TRANSCULTURAL}

Hassan, Riaz. A Way of Dying: Suicide in Singapore 223

Livingston, Martha and Lowinger, Paul. The Minds of the Chinese People: Mental Health in New China 223

WHO Study Group. Mental Health Care in Developing Countries: A Critical Appraisal of Research Findings 455

We would like to thank the following who have acted as specialist assessors of original papers

\begin{tabular}{|c|c|c|c|c|}
\hline $\begin{array}{l}\text { M. T. Abou-Saleh } \\
\text { P. Abraham } \\
\text { P. Ainsworth } \\
\text { G. Ashcroft } \\
\text { A. W. Asscher } \\
\text { Doreen Asso } \\
\text { J. H. J. Bancroft } \\
\text { D. Bannister } \\
\text { T. R. E. Barnes } \\
\text { B. Barraclough } \\
\text { C. Bass } \\
\text { M. Beary } \\
\text { P. Bebbington } \\
\text { Linda Beeley } \\
\text { S. Benjamin } \\
\text { D. Bennett } \\
\text { G. Bennett } \\
\text { I. Berg } \\
\text { K. Bergmann } \\
\text { G. E. Berrios } \\
\text { P. J. V. Beumont } \\
\text { Joan Bicknell } \\
\text { J. L. T. Birley } \\
\text { J. Birtchnell } \\
\text { R. S. Bluglass } \\
\text { S. Brandon } \\
\text { C. Brewer } \\
\text { G. Brindley } \\
\text { A. C. Brown } \\
\text { G. W. Brown } \\
\text { A. Burke } \\
\text { M. W. P. Carney } \\
\text { B. J. Carroll } \\
\text { G. M. Carstairs } \\
\text { D. Chiswick }\end{array}$ & $\begin{array}{l}\text { A. D. Clayden } \\
\text { J. P. Cobb } \\
\text { P. H. Connell } \\
\text { J. Cookson } \\
\text { A. F. Cooper } \\
\text { P. Cooper } \\
\text { J. Copeland } \\
\text { T. Coughlan } \\
\text { J. L. Cox } \\
\text { J. L. Crammer } \\
\text { F. Creed } \\
\text { T. J. Crow } \\
\text { K. Davison } \\
\text { K. Day } \\
\text { J. F. W. Deakin } \\
\text { D. H. Dick } \\
\text { J. Dominian } \\
\text { Caroline Doré } \\
\text { G. Dunn } \\
\text { D. Eccleston } \\
\text { M. D. Enoch } \\
\text { B. S. Everitt } \\
\text { L. H. Fagin } \\
\text { I. N. Ferrier } \\
\text { C. D. Frith } \\
\text { M. E. Garralda } \\
\text { Ann Gath } \\
\text { M. G. Gelder } \\
\text { J. P. Gent } \\
\text { C. Godber } \\
\text { D. Goldberg } \\
\text { P. J. Graham } \\
\text { D. G. Grahame-Smith } \\
\text { K. L. Granville- } \\
\text { Grossman } \\
\text { (a) }\end{array}$ & $\begin{array}{l}\text { J. H. Gruzelier } \\
\text { J. Gunn } \\
\text { S. Gupta } \\
\text { H. Gurling } \\
\text { J. R. Hamilton } \\
\text { M. Hamilton } \\
\text { M. A. Harper } \\
\text { J. A. Harrington } \\
\text { G. Hay } \\
\text { B. Heine } \\
\text { P. Higgins } \\
\text { S. R. Hirsch } \\
\text { G. T. Hollingsworth } \\
\text { W. I. Hume } \\
\text { A. L. Johnson } \\
\text { D. A. W. Johnson } \\
\text { Eve C. Johnstone } \\
\text { D. J. Jolley } \\
\text { G. H. Jones } \\
\text { H. Gwynne Jones } \\
\text { J. Jutai } \\
\text { J. Kahn } \\
\text { J. H. Kahn } \\
\text { D. Kelly } \\
\text { R. E. Kendell } \\
\text { F. E. Kenyon } \\
\text { I. Kolvin } \\
\text { N. Kreitman } \\
\text { R. Kumar } \\
\text { M. H. Lader } \\
\text { P. L. Lantos } \\
\text { R. Levy } \\
\text { M. Lipsedge } \\
\text { W. A. Lishman } \\
\text { R. Littlewood } \\
\text { (a) }\end{array}$ & $\begin{array}{l}\text { G. G. Lloyd } \\
\text { C. McCance } \\
\text { H. A. McClelland } \\
\text { R. F. McCreadie } \\
\text { P. McGuffin } \\
\text { A. V. P. Mackay } \\
\text { G. P. Maguire } \\
\text { R. Marchbanks } \\
\text { I. Marks } \\
\text { H. Mersey } \\
\text { E. Miller } \\
\text { H. G. Morgan } \\
\text { S. Morley } \\
\text { J. K. W. Morrice } \\
\text { Brenda Morris } \\
\text { Elaine Murphy } \\
\text { R. Murray } \\
\text { D. Nutt } \\
\text { J. Orford } \\
\text { I. Oswald } \\
\text { C. M. B. Pare } \\
\text { C. M. Parkes } \\
\text { E. S. Paykel } \\
\text { J. R. Pedder } \\
\text { T. Pilkington } \\
\text { J. Pippard } \\
\text { B. Pitt } \\
\text { S. Platt } \\
\text { S. J. Pocock } \\
\text { D. A. Primrose } \\
\text { P. H. Rack } \\
\text { D. Raistrick } \\
\text { A. H. Reid } \\
\text { T. Reilly } \\
\text { Adrianne Reveley }\end{array}$ & $\begin{array}{l}\text { M. A. Reveley } \\
\text { Naomi Richman } \\
\text { K. J. B. Rix } \\
\text { R. Rodnight } \\
\text { P. Royston } \\
\text { O. Russell } \\
\text { D. R. Rutter } \\
\text { M. Rutter } \\
\text { B. I. Sacks } \\
\text { C. P. Seager } \\
\text { D. M. Shaw } \\
\text { A. C. P. Sims } \\
\text { N. Smeeton } \\
\text { H. Standish-Barry } \\
\text { R. S. Stern } \\
\text { J. Strang } \\
\text { N. Tarrier } \\
\text { M. J. Tarsh } \\
\text { F. Kräupl Taylor } \\
\text { Katherine Tress } \\
\text { Margaret Vaughan } \\
\text { Christine Vaughn } \\
\text { P. H. Venables } \\
\text { A. Wakeling } \\
\text { Helena Waters } \\
\text { J. P. Watson } \\
\text { D. Weeks } \\
\text { M. Weller } \\
\text { D. J. West } \\
\text { Sheila M. Willatts } \\
\text { P. Willmott } \\
\text { J. Wing } \\
\text { Lorna Wing } \\
\text { S. Wolkind } \\
\text { Maria A. Wyke }\end{array}$ \\
\hline
\end{tabular}

